УДК 37.016:811.161.2

DOI

Анна Огар, кандидат філологічних наук, старший викладач кафедри філологічних дисциплін та методики їх викладання у початковій школі Дрогобицького державного педагогічного університету імені Івана Франка Марія Кріль, магістр факультету початкової та мистецької освіти Дрогобицького державного педагогічного університету імені Івана Франка

\title{
ФОРМУВАННЯ РИТОРИЧНОЇ КУЛЬТУРИ УЧНЯ ПОЧАТКОВОЇ ШКОЛИ ЗАСОБАМИ ПАРЕМІОЛОГІї: КОНЦЕПТУАЛЬНИЙ АСПЕКТ
}

У статті йдеться про паремії як засіб формування риторичної культури учня початкової школи. 3 'ясовано, що велика група прислів 'їв і приказок містить рекомендації щодо правил спілкування, які упродовж віків виробляв наш народ. Насамперед національний фольклор засуджує розмови, не підкріплені діями; надмірну балакучість; неправдиві і жорстокі слова. Натомість позитивно оцінює виважену правдиву мову.

Ключові слова: пареміологія; паремія; прислів'я; приказки; риторика; риторична культура; концептуальний смисл.

Jim. 8.

Anna Ohar, Ph.D.(Philology), Senior Lecturer of the Philological Disciplines and Methods of their teaching at the Elementary School Department Drohobych Ivan Franko State Pedagogical University

Mariya Kril, Master of Faculty of Primary and Arts Education Drohobych Ivan Franko State Pedagogical University

\section{FORMATION OF THE RHETORICAL CULTURE OF THE PRIMARY SCHOOL PUPILS WITH THE MEANS OF PAREMIOLOGY: A CONCEPTUALASPECT}

The article deals with paremias as a means of forming the rhetorical culture of primary school pupils. A large group of proverbs and sayings has been found to contain guidelines for the rules of communication that our people have produced over the centuries. First of all, national folklore condemns; excessive talkativeness; false and cruel words. Instead, it appreciates prudent true language.

The paremological fund actualizes contextual antonyms such as conversation - reason, conversation - act, conversation - truth. Universal ethical opposition good - evil is also reflected in the paremias concerning the rules of communication. The good word inspires, supports, warms the soul, and the evil word destroys and degrades.

An important conceptual guideline in paremies is "silence is often better than speaking". These paremies give a direct indication of the behavior of the communication, but also to a certain extent stimulate the comprehension of what is heard, of the experience, and not of empty talk.

Separately distinguish the often actualized negative model word - not gender, which seeks to eliminate the identity of the word and something frivolous, irrelevant.

The lexical-semantic groups "arms", "musical instrument", "bird", "food", "textile, embroidery technique", "treasure, money" are the donor zones for the metaphorization of the word. Such metaphorical models convey the word's ability to hurt like a weapon; its elusiveness, like that of a bird; properties sound beautifully borrowed from musical instruments; fat and sweetness inherent in food; beauty and fluidity of embroidery and value for money.

Different types of work with paremias will not only promote speech development, but will also familiarize students with the rules of rhetorical communication, enhance their communicative culture.

Keywords: paremology; paremia; proverbs; sayings; rhetoric; rhetorical culture; conceptual sense.

П остановка проблеми. Сучасні програми для початкової школи зазначають, що однією 3 ключових компетентностей, формування якої передбачає мовно-літературна освітня галузь, $\epsilon$ комунікативна. На їі становлення націлені усі змістові лінії, серед яких виокремимо змістову лінію "Взаємодіємо усно", що спрямована на формування в учнів умінь сприймати, аналізувати, інтерпретувати й оцінювати усну інформацію, використовувати іiі в різних комунікативних ситуаціях, а також, що важливо, спілкуватися усно 3 іншими людьми в діалогічній і монологічній формах задля досягнення певної мети [6]. Вагомість таких умінь зумовлена потенціалом мови як засобу переконання, що особливо актуально в насиченому засобами масового зв' язку сьогоденні.

Аналіз наукових досліджень. До проблеми опанування теоретичних основ риторики й 


\section{ФОРМУВАННЯ РИТОРИЧНОЇ КУЛЬТУРИ УЧНЯ ПОЧАТКОВОЇ ШКОЛИ ЗАСОБАМИПАРЕМІОЛОГЇ: КОНЦЕПТУАЛЬНИЙ АСПЕКТ}

оволодіння відповідними практичними уміннями та навичками в науковому дискурсі апелювали С. Абрамович, В. Вандишев, Н. Колотілова, Л. Мацько, М. Пентилюк, Г. Сагач. Л. Мацько наголошує, що формування гармонійно розвиненої особистості без інтелектуально-естетичного впливу мови неможливе, в якій би сфері суспільно-виробничої діяльності не реалізовувалась людина. Уміння побудувати розгорнутий монолог $з$ фахової проблематики, виголосити його, аргументовано дискутувати, природно вести цікаву бесіду чи конструктивний діалог, не відчуваючи браку слів, знайти своє місце в полілозі, ненав'язливо підтримувати розмову, доречно зауважити чи просто шляхетно звернутися - цьому вчить лінгвістична риторика, яка завершує формування мовнокомунікативної компетенції мовця [3, 520]. Навички такого плану варто розвивати з перших днів дитини в школі.

Мета статті - 3'ясувати головні настанови паремій як засобу формування риторичної культури учня початкової школи.

Джерельною базою дослідження послугували народні афоризми, що характеризують людину, іiі життя, риси характеру та моральні орієнтири, упорядковані в збірку, матеріал до якої добирався з усіх відомих друкованих видань прислів ”їв та приказок (К. Зіновієва, В. Смотрицького, Г. Ількевича, М. Номиса, П. Чубинського, І. Манжури, Б. Грінчека, I. Франка тощо [4].

Виклад основного матеріалу. Дослідники виділять 4 етапи навчання риториці з метою досягнення високого рівня володіння мисленнєвомовленнєвою та комунікативною діяльністю [5, 176 - 177]. Перший і другий етапи - охоплюють початкову школу. Зокрема, на першому етапі (1 3 класи) школярам варто робити перші кроки в оволодінні художнім читанням, виразним читанням, основами спілкування. Для цього треба виразно читати тексти різного характеру, ретельно аналізувати їх, розкривати головну ідею, авторський задум, критично осмислювати й аналізувати прочитане, висловлювати власну думку стосовно прочитаного тощо. Другий етап (4 -6 класи) номінують школою діалогу і культури спілкування: дібрані твори мають стимулювати в учнів формування умінь та навичок ведення конструктивного діалогу, спілкування у формі діалогу, полілогу.

У результаті опанування риторики у молодших школярів мають сформуватися такі уміння та навички:

- вести розмову на побутові, політичні, ділові, філософські, історичні та інші теми, що входять до кола освіченої людини;
- слухати співрозмовника, ставити запитання, коректно й етично вставляти репліки, долучатися до розмови, розвиваючи тему, наводити аргументи щодо обговорюваної проблеми;

- брати участь у дебатах з проблеми, у якій дискутант є компетентним, викладає свої думки й судження за нормами літературної мови на рівні строго регламентованих вимог до виступу;

- брати участь у дискусіях, суперечках, дотримуючись усіх логічних, етикопсихологічних і комунікативних законів і правил; послідовно й доказово відстоювати свої погляди, спрямовані на конструктивне розв'язання проблеми;

- виступати перед аудиторією із невеликою, різною за жанрами промовою на доступну тему, ситуативно коректуючи їі зміст, обсяг;

- викладати свої думки у формі листа, статті; гречно висловлювати оцінки, переконання, коментарі стосовно певного жанру;

- заглиблюватися в задум чужого письмового чи усного мовлення; розуміти його внутрішній зміст, глибинні цілі, тобто ефективно читати й слухати, давати загальнориторичну оцінку прослуханого;

- мати розвинене мовне чуття, інтуїцію оратора, який гостроестетично сприймає текст, художнє слово;

- виокремити риси національної специфіки виступів та риторичних текстів із скарбниці українського красномовства [5, 176 - 177].

Як бачимо, початкові етапи навчання риториці припадають на 1 - 4 класи. Саме тут закладають основи риторичних знань, зокрема тут починається формування риторичної культури. Науковці трактують риторичну культуру як високий рівень оволодіння знаннями основ риторики та реалізацію їх у різних видах професійно-риторичної діяльності (навчальновиховній, науково-дослідній, художньо-естетичній, громадській, культурній тощо) [7, 218]. Складниками риторичної культури $\epsilon$ спрямованість на оволодіння мистецтвом виразного й переконливого слова; знання основ риторичної культури; комплекс спеціальних здібностей і практичних умінь; техніка (поставлений приємний голос, чітка дикція i правильна вимова; інтонаційна різноманітність словесної партії; доцільне використання невербальних засобів виразності; здатність до створення в собі творчого піднесеного самопочуття й передачі його співрозмовнику); характер і результативність мовлення у різних видах діяльності (здатність до критичного аналізу риторичної культури в конкретних видах діяльності, самокритичність в оцінюванні іiі, 

КОНЦЕПТУАЛЬНИЙАСПЕКТ

готовність до оперативного корегування) [7, 218 $-219]$.

Різноманіття форм роботи у контексті зазначеної проблеми все ж обмежене у початковій школі. Пошук ефективних способів формування риторичної культури молодших школярів змушує розглядати доступні для них форми та жанри, серед яких - паремії. Паремія, за трактуванням дослідників, - це мовна одиниця, що вирізняється афористичністю, усталеністю, відтворюваністю, переосмисленим чи буквальним узагальненим значенням, здебільшого повчальним змістом, мовний знак, який передає специфічну інформацію про традиційні цінності та погляди, грунтовані на життєвому досвіді народу, позначає типову життєву ситуацію $[2,16]$. Ці різновиди фольклору концентрують спосіб мислення українського народу, його розуміння навкілля. Релевантні аспекти людського життя отримали загальнонародне осмислення й матеріалізацію у прислів'ях і приказках, які акумулюють певні норми національної поведінки, зокрема й спілкування. Тож ми насамперед розглянемо паремії відповідно до правил спілкування.

У науковому дискурсі уже розроблено класифікації паремій. Не оминули науковці увагою й одиниць, що стосуються етикету спілкування. Скажімо, Г. Бондаренко послуговується визначеними Ю. Рождественським трьома категоріями: правилами організації діалогу, правилами для мовця й правилами для слухачів [1]. Правила для організації діалогу визначають ставлення людей у діалозі (знання форм мовленнєвого етикету, заборона неввічливого мовлення і рекомендація ввічливості, заборона ображання словом), порядок ведення бесіди (передування слова несловесній дії, прерогативація слухання над говорінням, умовчування). Правила для мовців поділяються на п'ять розрядів: обережність, задум, підготовка промови, типові помилки, невербальні засоби вираження. Правила для слухачів розгалужені й охоплюють оцінку мовлення оратора, відділення істинних i хибних, правдоподібних i неправдоподібних, потрібних і непотрібних висловлювань [1].

Зважаючи на те, що семантична класифікація паремій на позначення особливостей спілкування уже $є$, пропонуємо рубрикувати ці одиниці в концептуальній площині-виділити концептуальні домінанти - смислові центри - на основі критеріїв частотності, семантичної місткості, загальновідомості. Така класифікація не просто упорядковує паремії, а дає змогу визначити національні особливості спілкування, виявити певні етнічні пріоритети, тобто сказати про культуру народу щось непересічне, нетривіальне, таке, що вирізняє ії зпоміж інших.

Першим таким концептуальним центром $є$ смисл “слова протиставлені діям”. Процес говоріння у такому контексті - це щось легке, безвідповідальне, ілюзорне, а дії - таке, яке вимагає зусиль, реальне : Діла на копійку, а балачок на карбованець. Набалакала много, а нема нічого з того. Хто багато говорить, той мало творить. Багато казали, а потім руки склали. Найменше діло - балакать. Менше говори - більше діла твори. Наслідком такого говоріння є змарнований час, тому пареміологія засуджує пусту балаканину: Красно говорить, а слухати нічого. Городить таке, щзо й купи не держиться. Плете, щуо слина до губи принесе. Нема чого говорити, а є щзо балакати. Останні приклади ілюструють семантичну амбівалентність: лексеми говорити, балакати, плести, які є загальномовними синонімами, постають як антагоністи (висловлювати думки обдумано/необдумано). Антонімами до слова говорити також постають й номени бридня, видумка, верзти, галу-балу. Тобто мова є лише тоді позитивно маркованою, коли вона добре обдумана, слова виважені, що виразно окреслено смислово "говорити розумно": Що думаєш сказати, спершу обміркуй. Говорити - не горох молотити. Вкусися перше за язик, поки що скажеш. Говорити $i$ не думати - те саме, щзо стріляти і не ціілити. Бесіди багато, а розуму маловато. Не все те казати, шзо на рот лізе. Загалом дослідження пареміологічного фонду дає змогу висновкувати, що український народ засуджує розходження слова 3 ділом. Така оцінка слугує своєрідним правилом мовлення "Говори відповідально".

Наступний концептуальний центр “слова правда". В українському ментальному просторі й концепт правда, і концепт слово - це ключові одиниці. Перший втілює істинність i справедливість, другий - голос внутрішнього світу людини, народу, носій їхнього духу. Пересічення цих концептів утворює позитивно марковане словосполучення правдиве слово, антонімійними до якого є компоненти чималої кількості паремій: I від солодких слів буває гірко. На словах медок, а на сериі льодок. Слово з маслом, та думка чортова. Слова ласкаві, та думки лукаві. Говорить, як лисиця, а за пазухою камінь держить. Тож часто вербально зв'язок слова і правди передано саме через протилежні поняття. Як правило, українська пареміологія розмежовує правду і слова, що постають як 
порожні розмови. Саме правда робить слово дійсно цінними: Мало говори, а правдою дорожи. Хто багато говорить, той мало правди каже. Водить за ніс, а правди не скаже. Де мало слів, там більще правди. Красно говорить приятель, а правду скаже неприятель.

Ще один концептуальний критерій “мовчання часто краще за говоріння": Не мовчанка буває нудна, а пуста балачка. Нема чим бурчати, то ліпше мовчати. Говорити - то срібло, в мовчати - то золото. Не соромно мовчати, як нічого сказати. Умій впору $і$ помовчати. Хто мовчить, той двох навчить. Хто мовчить, той більше знає. Не все говори, щзо знаєш, та все знай, щуо хочеш говорити. Слухай тисячу разів, а говори один раз. Такі паремії не тільки дають пряму вказівку до способу поведінки за комунікації, але також певною мірою стимулюють до осмислення почутого, здобуття досвіду, а не до пустих балачок: Хто щцо говорить доброє, то ти на ус мотай. Хоча мовчання може актуалізувати й менш типові смисли: Мовчанка признання до вини. Мовчання - знак згоди.

Багато уваги пареміологія приділяє універсальній концептуальній етичній опозиції добро - зло. Накладається ця пара і на одиниці, що формують модель комунікативної поведінки. Зокрема підкреслено роль доброго, щирого слова на противагу слову злому: Добре слово дорожче багатства. Добре слово не коштує нічого, а поможе багато. Добрим словом мур проб'єш, а лихим $і$ в двері не ввійдеш. Лагідні слова роблять приятелів, а острі - завзятих ворогів. Оті серцем не старіють, які щирі слова сіють. Вода все сполоще, тільки злого слова ніколи. Бризнув му в очі лихим словом. Вербалізація народної мудрості виявляє винахідливість та образність національного мислення. Скажімо, для передачі концепту слово у пареміології реалізовано метафоричні моделі як один із способів обробки та концептуалізації знання:

- слово - музичний інструмент: На словах як на ичимбалах. На речах, наче на кобзі. На словах, як на органах, а як до діла - ані гу-гу. На словах, як на гуслях, а на ділі, як на балалайці грають;

- слово - зброя: Ніж ранить тіло, а слова душу. Слово - не стріла, а глибше ранить. Словом заб'єш більше, ніж дубиною. Шабля ранить голову, а слово - душу. Бджола ранить жалом, а чоловік - словом;

- слово - їжа: Слово з маслом, а думка чортова. Слова, як мед, діла, як полин;

- слово - птах, частина його тіла: Слова, як пташка, випустиш, не повернеш. Слово - не горобець: випустиш - не піймаєш. Слово вилетить горобцем, а вернеться волом. Ваше слово з крилами;

- слово - текстиль, техніка вишивання: Словом, як шовком вишиває, а ділом, як шилом шпигає. Словом, як низзю стеле, а ділом, як голками, коле. Слово - не прапор, а високо водить;

- слово - скарб, дорогоцінність, гроші: Слово дорожче золота. Слово старше, ніж громі. Слово - срібло, мовчання - золото. Добре слово дорожче багатства.

Окремо варто виділити часто актуалізовану заперечну модель слово - не полова, якою прагнуть нівелювати тотожність слова і чогось несерйозного, несуттєвого. Але сам факт наявності таких паремій засвідчує побутування саме трактування слова як незначного, що не має матеріальної цінності: Що поможе говорити, як нема що в рот вложити; Теплими словами хати не нагрієш. Зіставлення паремій ілюстує кардинально протилежні концептуальні засади. Скажімо, остання наведена одиниця декларує некорисність слів, їхню марність. Натомість паремія Теплі слова зігрівають душу людині навпаки. Тож слова, мова - це категорії не матеріального, а духовного плану; саме в такій площині варто шукати розуміння їхньої цінності.

Як бачимо, слово концептуалізовано через характеристики різних предметів: здатність причиняти біль зброї, невловимість птаха, властивості красиво звучати музичних інструментів, масність і солодкість їжі, красота та плавність вишивки й, щонайважливіше, цінність грошей. Так бачив слова український народ і так заклав у фольклорі. Для формування риторичної культури учня ці паремії дають такі посили: словом можна ранити; слова треба обдумувати, бо назад їх не вернеш; за гарними словами не завжди стоять гарні діла; слова - це не порожні балачки, а духовна зброя. Це врахували укладачі підручників для початкової школи і вплели у тексти книг такі прислів'я та приказки: Умій сказати, умій $і$ змовчати. Слово-не горобейь, вилетить - не впіймаєш. Від теплого слова $i$ лід розмерзає. Гостре словечко коле сердечко. Не той друг, хто медом маже, а той, хто правду каже. Хто мудро мовчить, гарно говорить. Слова треба зважувати, а не рахувати. Швидкий буде слухати, а повільний говорити.

Загалом ретельний аналіз паремій дає змогу виявити певні вимоги до слова-мови: це виявляється передусім через негативний 


\section{ФОРМУВАННЯ РИТОРИЧНОЇ КУЛЬТУРИ УЧНЯ ПОЧАТКОВОЇ ШКОЛИ ЗАСОБАМИПАРЕМІОЛОГЇ: КОНЦЕПТУАЛЬНИЙ АСПЕКТ}

(загальновідомо, що в мові переважають усталені вирази на позначення негативних якостей, на ГОДСТАРЕВ СЛІОВАЕЧМКОЇ КОТЛЕЬ засудження) компонент контекстуальних

\section{СЕЮРДЯЕЧЦКОЗ}

- відгадай прислів'я:

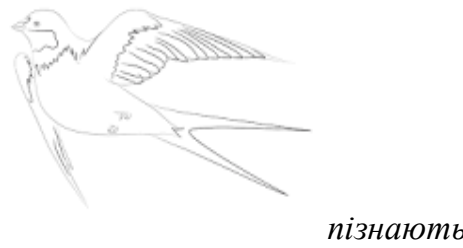

Птищю пізнають по пірю, а людину по бесіді

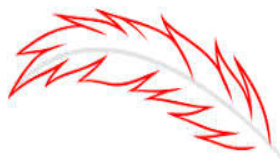

, $a$

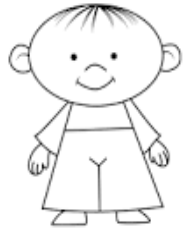

Птицю пізнають по пірю, а людину по бесіді

- складіть розповідь за прислів'ям Слово - не горобець, вилетить - не впіймаєш "Чому не можна зловити слово?"

Різні види роботи з пареміями не лише сприятимуть мовленнєвому розвитку, а й ознайомлять учнів 3 правилами риторичного спілкування, підвищать їхню комунікативну культуру. Прислів'я та приказки засуджують розходження слів із ділами, зайву балакучість, невміння тримати язик за зубами, але схвально ставляться до обдуманої, правдивої мови; радять більше мовчати, аніж говорити.

Висновки та перспективи подальших досліджень. Підсумовуючи, скажемо, що формування риторичної культури учнів початкової школи - необхідна умова становлення риторичної компетентності як складника мовної особистості; пареміологія - важливе джерело здобуття знань, бо конденсує в доступній формі досвід про правила риторичної взаємодії; серед паремій $є$ група одиниць, які регулюють правила комунікації; головні настанови таких одиниць: слова мають відповідати діям, слова мають нести правду, варто більше мовчати та вчитися.

\section{насамкінець - із кругів:}

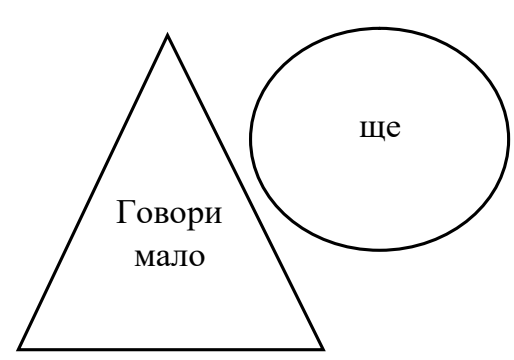

- прочитайте прислів'я, запишіть, якими можуть бути слова:

Бджола жалить жалом, а чоловік словом.

Від теплого слова і лід розмерзає.

Слова ласкаві, та думки лукаві.

- викресліть кожну третю букву і запишіть прислів'я:

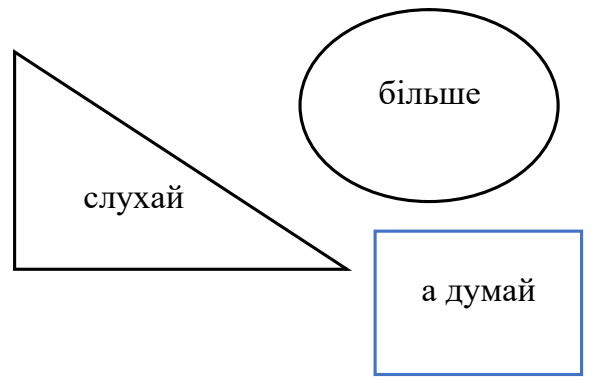

\section{ЛІТЕРАТУРА}

1. Бондаренко Г. Л. Формування риторичної культури молодшого школяра засобами народного золотослова. Психолого-педагогічні проблеми сільської школи. 2006. № 8. URL: http:// library.udpu.org.ua/library files/ psuh_pedagog_probl_silsk_shkolu/8/visnuk_15.pdf (дата звернення 12.07.2019) 
2. Колоїз Ж. В., Малюга Н. М., Шарманова Н. М. Українська пареміологія : навчальний посібник для студентів філологічних спеціальностей вищих навчальних закладів. Кривий Ріг, 2014. 349 с.

3. Мацько Л. Українська мова в освітньому просторі: навчальний посібник для студентівфілологів остітньо-кваліфікаційного рівня “Магістр". Київ, 2009. 607 с.

4. Пазяк М.M. Прислів'я та приказки : Людина. Родинне життя. Риси характеру. Київ, 1990. $528 \mathrm{c}$.

5. Сагач Г. Риторика. Київ, 2000. 567 с.

6. Українська мова. Навчальна програма для загальноосвітніх навчальних закладів 1-4 класи. URL: https://mon.gov.ua/ua/osvita/zagalna-serednyaosvita/navchalni-programi/navchalni-programi-dlyapochatkovoyi-shkoli (дата звернення 14.07.1985)

7. Усатий А. В. Формування риторичної культури майбутнього вчителя-словесника. Педагогічна риторика: історія, теорія, практика : монографія / Кучерук О. А., Голуб Н. Б., Горошкіна О. М. та ін.; за ред. О. А. Кучерук, 2016. 258 c. С. $217-229$.

8. Хорт М. К. Вивчення малих фольклорних жанрів у початковій школі. Методичні рекомендації з методики викладання української мови для студентів спеціальності 6.010102 Початкова освіта. Прилуки, 2011. 99 с.

\section{REFERENCES}

1. Bondarenko, H. L. (2006). Formuvannya rytorychnoyi kultury molodshoho shkolyara zasobamy narodnoho zolotoslova [Formation of rhetorical culture of the junior schoolboy by means of folk gold-digger]. Psychological and pedagogical problems of rural school. No. 8. Available at: http://library.udpu.org.ua/ library_files/psuh_pedagog_probl_silsk_shkolu/8/ visnuk_15.pdf (accessed 10 July 2019). [in Ukrainian].

2. Koloyiz,Zh. V., Malyuha, N. M. \& Sharmanova, N. M. (2014). Ukrayinska paremiolohiya [Ukrainian paremology]. Kryvyi Rih, 349 p. [in Ukrainian].

3. Matsko, L. (2009). Ukrayinska mova v osvitnomu prostori: navchalnyy posibnyk dlya studentiv-filolohiv ostitno-kvalifikatsiynoho rivnya "Mahistr" [Ukrainian language in the educational space: a textbook for students-philologists of the master's degree-qualification level]. Kyiv, 607 p. [in Ukrainian].

4. Pazyak, M. M. (Eds.). (1990). Pryslivia ta prykazky: Lyudyna. Rodynne zhyttya. Rysy kharakteru [Proverbs and sayings: Man. Family life. Character traits]. Kyiv, 528 p. [in Ukrainian].

5. Sahach, H. (2000). Rytoryka [Rhetoric]. Kyiv, 567 p. [in Ukrainian].

6. Ukrayinska mova. Navchalna prohrama dlya zahalnoosvitnikh navchalnykh zakladiv 1-4 klasy [Ukrainian language. Curriculum for Comprehensive Schools 1-4]. Available at: https://mon.gov.ua/ua/ osvita/zagalna-serednya-osvita/navchalni-programi/ navchalni-programi-dlya-pochatkovoyi-shkoli (accessed 14 July 2019). [in Ukrainian].

7. Usatyy, A. V. (2016). Formuvannya rytorychnoyi kultury maybutnoho vchytelya-slovesnykarafiya [Formation of rhetorical culture of the future teacherdictionary]. Pedagogical rhetoric: history, theory, practice: monograph. O. A. Kucheruk (Ed.). Kyiv, 258 p. [in Ukrainian].

8. Khort, M. K. (2011). Vyvchennya malykh folklornykh zhanriv u pochatkoviy shkoli [Tudy of small folklore genres in elementary school]. Guidelines for teaching the Ukrainian language for students of specialty 6.010102 - Primary education. Pryluky, 99 p. [in Ukrainian].

Стаття надійшла до редакції 09.08.2019

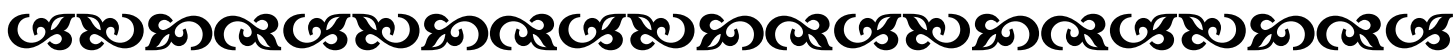

\author{
“Найбільша розқіш на світі - це розқіш людсьқого спілқування". \\ Антуан де Сент-Екзюоері \\ бранцузький письменник \\ “Від слова до слова людина іноді йде все життя”.
}

Станіслав Сжи Яєи “Сқажи мені що-небудь, щоб я тебе побачив".

польський поет, білособ, писъменник.

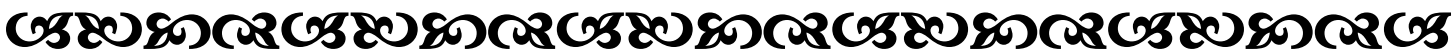

